\title{
$\mathrm{MDI}$ 第 3 成分とする $\mathrm{CF} / \mathrm{GF}$ ハイブリッド \\ 複合材料とその機械的特性 ${ }^{\dagger}$
}

\author{
好 満 芳 邦* 田平公孝** 杉 山一 男*** \\ 大 橋 俊 彦** 下原伊智朗**
}

\section{CF/GF Hybrid Composite Materials using MDI as Third Component and Their Mechanical Properties}

\author{
by \\ Yoshikuni Yoshimitsu*, Kimitaka TAHIRA**, Kazuo Sugryama*** \\ Toshihiko OHASHI ${ }^{* *}$ and Ichiro SHIMOHARA**
}

\begin{abstract}
In the previous work $^{1}$, isocyanate modification of epoxy acrylate resin (EPA) was studied to improve the mechanical properties of $\mathrm{CF} / \mathrm{GF}$ hybrid composite materials. In this work, some chemical reactions of diphenyl methan diisocyanate (MDI) as the third component with surface treatment agents of $\mathrm{CF}$ and GF were studied to improve the mechanical properties of the laminates. Epoxy silane and amino silane coupling agents were applied to GF surface in order to improve the interlaminar adhesion bonding. As the results, interlaminar shear strength and flexural bending strength were markedly improved, which indicated that some covalent bonds such as ester, urethan and urea bonds partially linked fiber surfaces with resin matrix.
\end{abstract}

Key words : FRP, Carbon fiber, Glass fiber, Hybrid composites, Epoxy acrylate, Fiber surface finishing, Resin modification, Interlaminar adhesive,

Mechanical properties

\section{1 緒言}

前報でイソシアネート変性エポキシアクリレート樹 脂と炭素繊維表面処理剤の特徴的な反応と複合材料特 性の改善例を報告した．その手法を拡大してゆくと興 味深い複合材料構成を提案することができる．すなわ ち化学的にセンシティブな系として，樹脂マトリック スと補強用瀻維の界面を形成している表面処理剂の両 者と反応性を有する第 3 成分を構成させる．この手法 は，特に，表面処理および特性の異なる異種瀻維を組 合わせて製造するハイブリッド複合材料の課題とされ てきた，層間特性の改善に有効である．例えば，不飽 和ポリエステル系 FRP は不飽和基の付加重合によっ て䋐維処理剤およびマトリックス樹脂との化学的結合 を狙っているため, エポキシコーティングされた炭素 繊維表面とは反応しない. 逆にエポキシシラン処理し たガラス繊維を用いてもスチレンとは反応しない，そ こでこのエポキシ基と反応し, 同時にマトリックス樹 脂骨格官能基とも反応する第 3 成分を配合することに よって, より強固な化学結合を有するハイブリッド複 合材料が形成されることが考えられる.
本報では，第 3 成分をイソシアネートとする $\mathrm{CF} /$ $\mathrm{CF}$ ハイブリッド複合材料の特徵的特性および破面観 察等を通してその有効性について考察してみたい.

\section{2 実 験 方 法}

\section{$2 \cdot 1$ エポキシァクリレート樹脂組成物}

エピビス系エポキシオリゴマー $(n=1.3)$ およびメ タクリル酸から第 4 級アンモニウム塩を触媒として付 加縮合により合成したエポキシアクリレートプレポリ マーのスチレン溶解樹脂（一般的なモル比 $1: 4$; 以下 EPA と略称）を調整し，実験に供した．第 3 成分と して用いたイソシアネートは, 多核ポリイソシアネー トとも呼ばれる, 変性ジフェニルメタンジイソシアネ 一ト (MDI) を採用し，ハイブリッド複合材料成形直 前に EPA 樹脂に混合して用いた．その配合率は， $\mathrm{EPA}$ の $\mathrm{OH}$ 当量に対して $25,50,75,100 \%$ 量とし た.これは EPAに対する重量添加率に換算してそれ ぞれ 5.4，10.8，16.2，21.6\% に対応している.これ らの配合処方を目的別に適用し，第 3 成分としての MDI による変性効果を検討した.オリゴマー $n$ 值 1.3 は, 予備実験での成形粘度・機械的特性のバラン 
スが良好であったことから採用した，硬化触媒は $t$-butyl peroxypivalate（1 phr 添加）を使用した。

\section{$2 \cdot 2 \quad \mathrm{CF} / \mathrm{GF}$ ハイブリッド複合材料}

$2 \cdot 2 \cdot 1$ CF 体積率別ハイブリッド複合材料 炭 素瀻維およびガラス瀻維は, 前報同様見掛け厚さが公 称 $0.25 \mathrm{~mm}$ である平織を採用した，本実験では，炭 素繊維およびガラス繊維の表面処理剤と化学的に活性 な MDI の第 3 成分としての作用を検討するために, $\mathrm{MDI}$ は EPA の $\mathrm{OH}$ 当量と同当量の添加量とした. ガラス㵶維は, ビニルシラン, エポキシシランあるい はアミノシランカップリング剤で，それぞれ， 0.1 wt.％の表面処理を施した試料を実験に供した，炭素 纎維は，前報同様エポキシコーティングされた， T300 相等品を使用した．積層板の基材構成は，式 (1), (2) で代表される炭素瀻維が上下最外層に配置された サンドイッチタイプとし，段階的にハイブリッド化率 を変動させた。

$$
\begin{aligned}
& \left(\mathrm{CFCL} / \mathrm{GFCL}_{m}\right)_{n}+\mathrm{CFCL} \\
& \left(\mathrm{CFCL}_{2} / \mathrm{GFCL}_{5}+\mathrm{CFCL}_{2}\right.
\end{aligned}
$$

$$
\begin{aligned}
& \text { ここで, } \\
& \text { CFCL : CF ロービング平織 }
\end{aligned}
$$

(PYROFIL TR3110)

\section{GFCL：GF ヤーン平織 (FECR2521)}

$m, n:$ 繰返し数

これらの詳細は Table Iにまとめて示す。

積層板は，それぞれの基材構成ごとに湿式積層後， スペーサー (3 mmt)を介して; 成形圧力 $0.98 \mathrm{MPa}$, 成形温度 $120^{\circ} \mathrm{C}$ および成形時間 $30 \mathrm{~min}$ の条件下で熱 プレス成形し，実験に供した。

$2 \cdot 2 \cdot 2$ MDI 添加率別ハイブリッド複合材料 積 層板の種類を $\mathrm{CFCL}_{16}, \mathrm{GFCL}_{11}$, および $(\mathrm{CFCL} /$ $\mathrm{GFCL})_{6}+\mathrm{CFCL}$ ハイブリッド材の 3 種類として, MDI の添加率を, $0,5.4$ (0.25 当量), 10.8 (0.5 当 量), 16.2 (0.75 当量), および 21.6 (1.0 当量) wt. $\%$ の 5 段階としてハイブリッド材に適用した. CF および GF 単独積層板については，0，10.8 および
$21.6 \mathrm{wt}$ \% \%の 3 段階を適用して試験板を成形し，実験 に供した，成形は，スペーサー $(2 \mathrm{mmt})$ を介して，成 形圧力 $0.5 \mathrm{MPa}$, 成形温度 $120^{\circ} \mathrm{C}$, 成形時間 30 分の 条件下で同様に熱プレス成形した。 ただし，ここで用 いた GFCL は 1 枚当たりの見掛け厚さが $0.3 \mathrm{~mm}$ (前 節で用いた GFCL は同 $0.2 \mathrm{~mm}$ ）のものを用いた.

\section{$2 \cdot 3$ 積層板の機械的特性および破面観察}

機械的特性は, 引張, 曲げ, 層間せん断, シャルピ 一衝撃，および貫通衝撃の各試験によって評価した. 貫通衝撃試験を除いて，下記に示す試験方法に準拠し て実施した。

$$
\begin{array}{lr}
\text { 引張試験 }(n=5) & \text { : JIS K 7054 } \\
\text { 曲げ試験 }(n=5) & : \text { JIS K 7054 } \\
\text { 層問せん断試験 }(n=5) & \text { : JIS K 7057 } \\
\text { シャルピー衝撃試験 }(n=10): \text { JIS K } 7111
\end{array}
$$

積層板の基材構成に敏感であると考えられる貫通衝 撃試験については，ほぼ面内曲げモードに近い領域で ある, 支持径／試験片厚さ比が 40 付近になる条件を 選択して行った：試験条件として，打撃ポンチ先端直 径 $12.7 \mathrm{~mm}$, 打撃速度 $6 \mathrm{~m} / \mathrm{s}$, 支持径 $99.6 \mathrm{~mm}$ を採用 し, 試験片寸法は, $110 \mathrm{~mm}$ 角正方形とし, 板厚は成 形厚さ $(2,3 \mathrm{~mm})$ とした（試料数 $n=3$ ). 貫通衝撃に よって生じる内部損傷領域の特定は, 超音波 $\mathrm{C}$ ス キャン（透過法）によって計測した，破面観察は， シャルピー衝撃破断片について光学顕微鏡（低倍率） および走查電子顕微鏡（高倍率）観察を行った.

\section{3 実験結果と考察}

\section{$3 \cdot 1 \mathrm{CF}$ 体積率とハイブリッド複合材料特性}

$3 \cdot 1 \cdot 1$ 層間せん断強さ 層間特性は, 層間の接 着力とタフネス (じん性) の両者で評価することが望

\begin{tabular}{|c|c|c|c|c|}
\hline \multirow{2}{*}{$\begin{array}{l}\text { Resin } \\
\text { system }\end{array}$} & \multirow{2}{*}{$\begin{array}{l}\text { Laminate } \\
\text { constitution }\end{array}$} & \multirow{2}{*}{$\begin{array}{c}\text { Surface } \\
\text { treatment } \\
\text { agent of GF }\end{array}$} & \multicolumn{2}{|c|}{$V_{f}(\%)$} \\
\hline & & & $\mathrm{CF}$ & GF \\
\hline $\begin{array}{l}\text { Conventional } \\
\text { EPA } \\
\text { system }\end{array}$ & $\begin{array}{l}\mathrm{GFCL}_{16} \\
\mathrm{CFCL} / \mathrm{GFCL}_{14} / \mathrm{CFCL} \\
\left(\mathrm{CFCL} / \mathrm{GFCL}_{3}\right)+\mathrm{CFCL} \\
\left(\mathrm{CFCL} / \mathrm{GFCL}_{2}\right)_{5}+\mathrm{CFCL} \\
\left(\mathrm{CFCL} / \mathrm{GFCL}_{8}+\mathrm{CFCL}\right. \\
\mathrm{CFCL}_{16}\end{array}$ & $\begin{array}{l}\text { Vinyl } \\
\text { silane }\end{array}$ & $\begin{array}{r}0 \\
7.8 \\
17.8 \\
22.1 \\
30.6 \\
53.3\end{array}$ & $\begin{array}{c}35.3 \\
35.0 \\
27.5 \\
23.7 \\
17.5 \\
0\end{array}$ \\
\hline $\begin{array}{l}\text { Third } \\
\text { component } \\
\text { (MDI) } \\
\text { added EPA } \\
\text { system }\end{array}$ & $\begin{array}{l}\mathrm{GFCL}_{16} \\
\mathrm{CFCL} / \mathrm{GFCL}_{14} / \mathrm{CFCL} \\
\left(\mathrm{CFCL} / \mathrm{GFCL}_{3}\right)+\mathrm{CFCL} \\
\left(\mathrm{CFCL} / \mathrm{GFCL}_{2}\right)_{5} / \mathrm{CFCL} \\
\left(\mathrm{CFCL} / \mathrm{GFCL}_{8}+\mathrm{CFCL}\right. \\
(\mathrm{CFCL})_{2} / \mathrm{GFCL}_{5}+\mathrm{CFCL} \\
\mathrm{CFCL}_{16}\end{array}$ & $\begin{array}{l}\text { Vinyl-, } \\
\text { amino-, } \\
\text { and epoxy- } \\
\text { silane } \\
\text { respectively }\end{array}$ & $\begin{array}{c}0 \\
6 \sim 8 \\
15 \sim 18 \\
18 \sim 22 \\
31 \sim 32 \\
35.7 \\
53 \sim 59\end{array}$ & $\begin{array}{l}30 \sim 32 \\
27 \sim 35 \\
23 \sim 28 \\
20 \sim 24 \\
17 \sim 27 \\
9.6 \\
0\end{array}$ \\
\hline
\end{tabular}
ましい.，しかしながら，後者の層間破壊じん性試験 は，予き裂の正確な計測が結果に大きく影響するが, ハイブリッド複合材料に関しては特別な工夫を施す場 合を除いて，予き裂の計測が現状では困難である。し たがって，層間せん断強さ（interlaminar shear strength : ILSS) で層間特性を評価することとした.

Table I. The composition of the laminates to be moulded. 


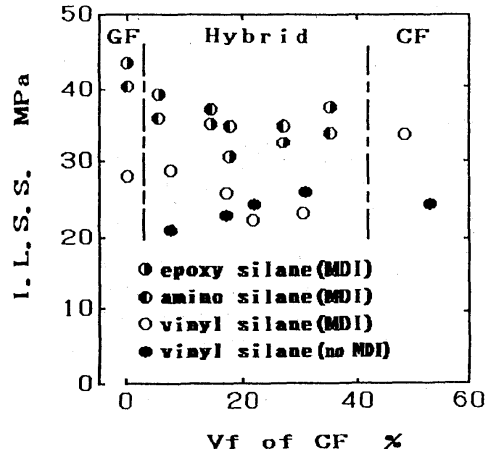

Fig. 1. ILSS versus $V_{f}$ of CFCL in each laminate.

Fig. 1 に繊維構成および表面処理剂それぞれの組合せ による積層板の ILSS を示す。ここで，プロットマ 一クに関する説明文はガラス繊維への表面処理剤の夕 イプを示している，炭素瀻維積層板の場合は，白抜き がMDI 添加，黒塗りが無添加を示している．以降他 の特性結果も同様である.ガラス繊維積層板に関して は，表面処理剂と MDI の効果が顕著に表れている. エポキシシランおよびアミノシランで処理された系が 第 3 成分として添加した MDI と強い結合力を発揮し たためと考えられる. ハイブリッド積層板に関しては, $\mathrm{CF}$ 体積率に対する相関関係が認められず，第 3 成分 と化学的に結合する性質を有する表面処理系が良好な 結果を示した．したがって，炭素瀻維積層板も同様に 第 3 成分を有する系が良好な層間結合力を示した。 こ れらの結果は, 鈴木らの報告と良く一致する傾向を示 している.これらの理論的考察についてはまとめて後 述する.

$3 \cdot 1 \cdot 2$ 引張特性 それぞれの積層板の引張弾性 率を Fig. 2, 引張強度を Fig. 3, および破断伸びを Fig. 4 にそれぞれ示す.

弾性率は $\mathrm{CF}$ 体積率増加に比例して増大している. これは, 応力ーひずみ線図の初期傾斜から求められる 特性であるため, 同線図全体の挙動から特性を判断す ることが重要である．特に破断伸びは第 3 成分の有無

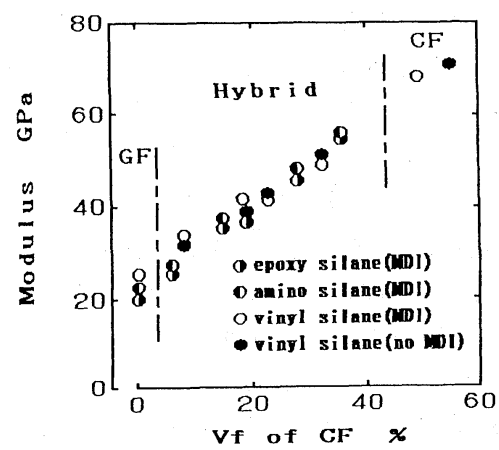

Fig. 2. Tensile modulus versus $V_{f}$ of CFCL in each laminate.

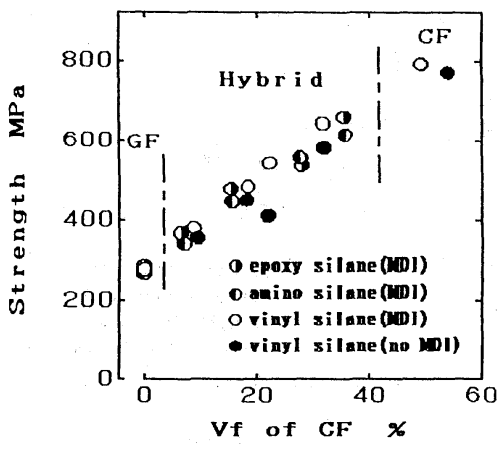

Fig. 3. Tensile strength versus $V_{f}$ of CFCL in each laminate.

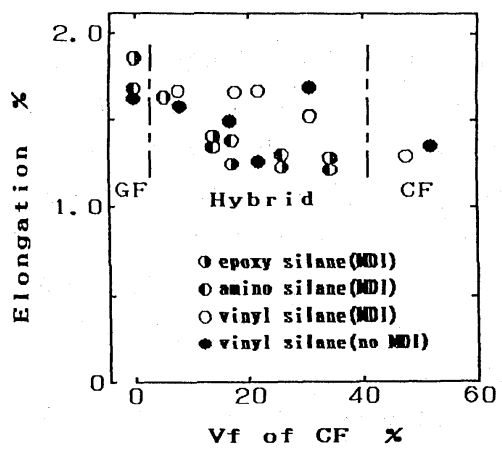

Fig. 4. Tensile elongation at break versus $V_{f}$ of CFCL in each laminate.

で大きく変化している．繊維表面処理剤-MDI-EPA の結合系を意図した積層板は，CF 体積率の上昇に 伴って破断伸びを減少させ，線形破壊に近い様相を呈 することを認めた.

$3 \cdot 1 \cdot 3$ 曲げ特性 曲げ特性は，積層板の層間特 性の影響を受け易い機械的特性であるため，比較的敏 感な結果を示すことが考えられる．弾性率および強度 のそれぞれのプロットを Fig. 5 および Fig. 6 に示す. 弾性率は，積層板最外層が炭素䋐維に置き代わっただ けで大きく増大し，炭素繊維体積率が $25 \%$ 付近まで はほほ同一である，さらに，最外層近傍の CF 層が

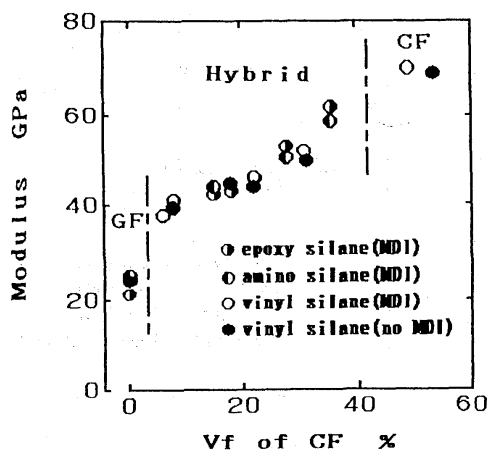

Fig. 5. Flexural bending modulus versus $V_{f}$ of CFCL in each laminate. 


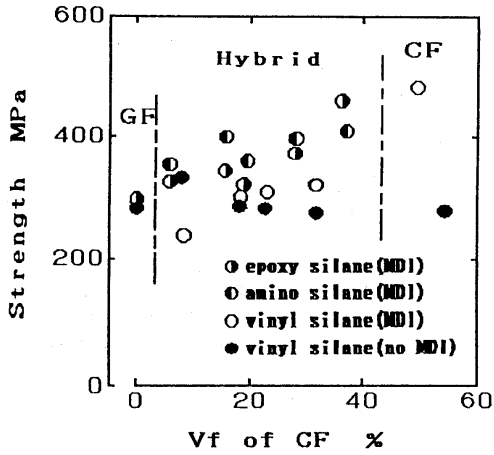

Fig. 6. Flexural bending strength versus $V_{f}$ of CFCL in each laminate.

増加するにつれて, 特性の増大を示して, 炭素䋐維系 で最大值をとる．前記したように，弾性率は応力ーひ ずみ線図の初期傾斜から求めるため, 繊維基材構成の 影響を強く受けるとともに，界面結合力を評価しきれ ないことを示している．強度に関しては，ハイブリッ ド系拧よび炭素瀻維系で表面処理剤および第 3 成分の 組合せによる層間結合力改善効果による特性の顥著な 増加が認められる.

$3 \cdot 1 \cdot 4$ 衝撃特性 先端複合材料分野を中心に, 熱硬化樹脂系複合材料のじん性扔よび耐衝撃性を改善 するための手法が多く報告されている．その代表的な ものはゴム成分等の改質剤的な添加物を導入する手法 がとられている. (6). B. Z. Jang らは, 薄肉積層板の衝撃 吸収エネルギーに関して, 主として補強瀻維の夕フネ スに影響を受けること, 衝撃破壊の主要因は層間およ び瀻維／樹脂界面破壊であることを報告している。衝 撃試験も層間および界面結合力に関連する評価手法の 一つである．本実験では，貫通およびシャルピー衝撃 試験を行って, 吸収エネルギー, 破壊モード，および 損傷面積をもとに第 3 成分-表面処理の影響について 検討した．その結果，シャルピー衝撃特性より貫通衝 撃特性がより材料組成による特性の差異を表現するこ とを認めた．それぞれの破壊吸収エネルギーを Fig. 7

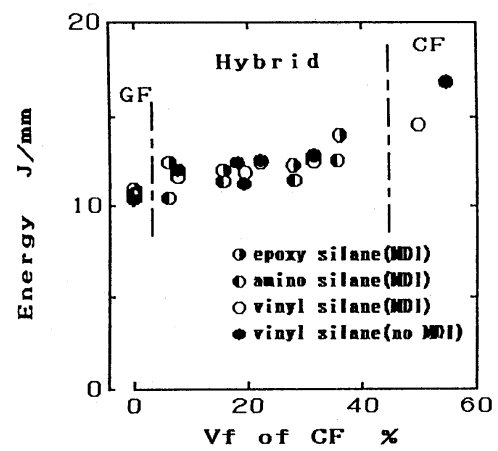

Fig. 7. Penetrating impact energy versus $V_{f}$ of CFCL in each laminate.

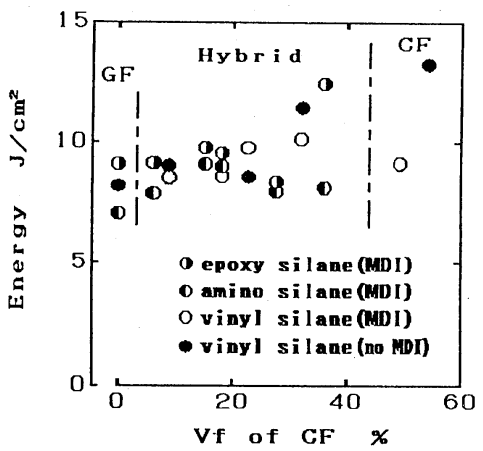

Fig. 8. Charpy impact energy versus $V_{f}$ of CFCL in each laminate.

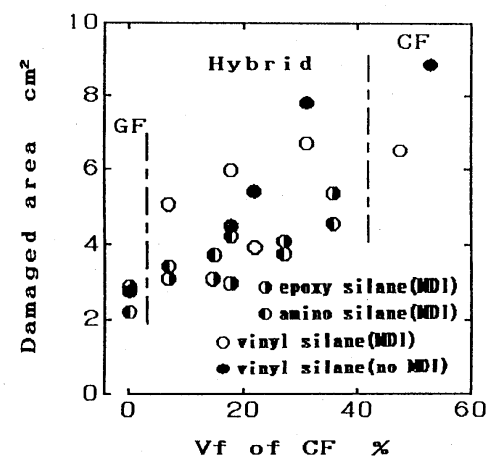

Fig. 9. Damaged area by penetrating impact versus $V_{f}$ of CFCL in each laminate.

および Fig. 8 にプロットした。貫通衝撃（Fig. 7) に ついては，板厚の影響を最小化するために吸収エネル ギーを板厚で除した値を採用した．Fig. 9 に示す衝撃 損傷面積プロットと合わせて耐衝撃性を評価した．衝 擊吸収エネルギーでは，第 3 成分を含まない系が相対 的に高い值を示す．それに対応して損傷面積も大きく なる傾向を示している。実用的には，吸収エネルギー が大きく損傷面積の小さな材料が望ましい，第 3 成分 の反応によってぜい性化が進むため, 吸収エネルギー の増大は望めないが，ハイブリッド系で，一部エポキ シシラン処理系に良好なものを認めた. 損傷面積は, 主として層間はく離領域の広さを示しているが，層間 接着性および界面結合力を改善すると考えられる．第 3 成分と表面処理剤の組合せの系で大きく改善されて いることが認められた. Fig. 10 抢よび Fig. 11 に炭素 纎維クロスとガラス繊維クロスの交互積層ハイブリッ ド系の変性による層間接着性および䋐維界面結合力の 改善状況を破面観察によって示した。 Fig. 10 はシャ ルピー衝撃破断片の低倍率拡大写真である. MDI 無 添加（Fig. 10(a)）では壊滅的な破壊が生じており， 詳細に観察すると，すべての $\mathrm{CF} / \mathrm{GF}$ 層間がはく離 していた．MDI 添加とシランカップリング剤の組合 せでは，エポキシシラン（Fig.10 (c)）扔よびアミ， 


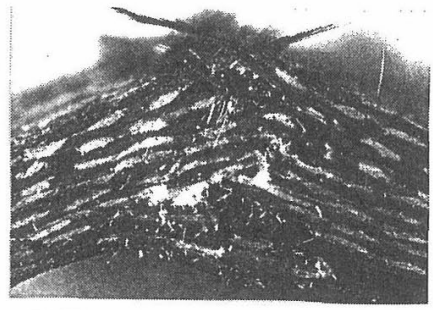

a) Ving 1 i inne (no MI)

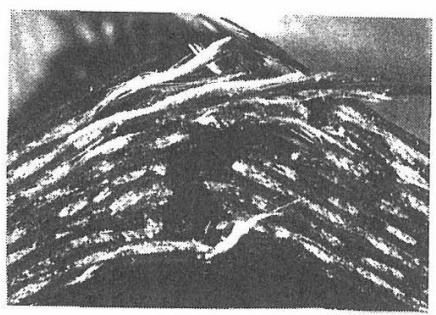

c) $\mathrm{Ep} 0 \mathrm{xJ}$ sine (MDI)

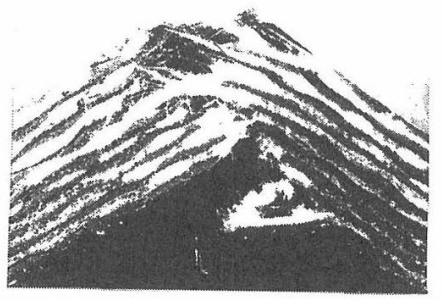

b) Ving 1 i i ane (MDI)

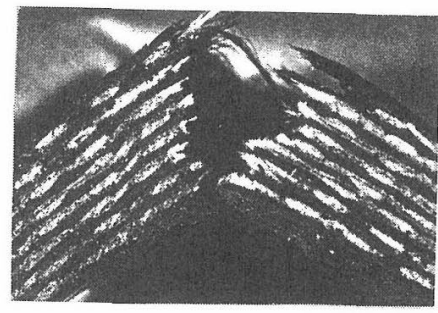

d) Amino ilane (MDI)

Fig. 10. Cross sections of $(\mathrm{CFCL} / \mathrm{GFCL})_{8}+\mathrm{CFCL}$ laminates after charpy impact.

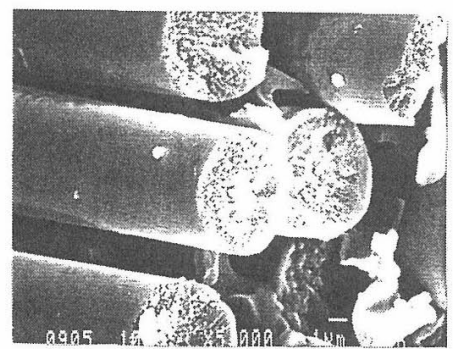

a) No MI

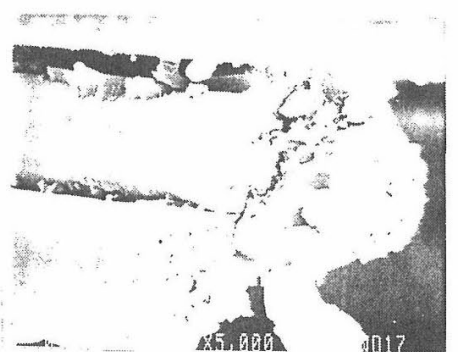

b) $\mathrm{MDI}$

\section{CF surface}

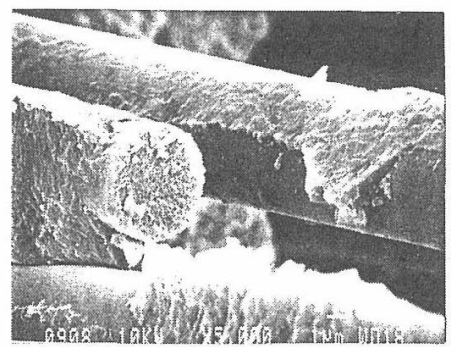

c) Ving 1 i 1 ane (no MDI)

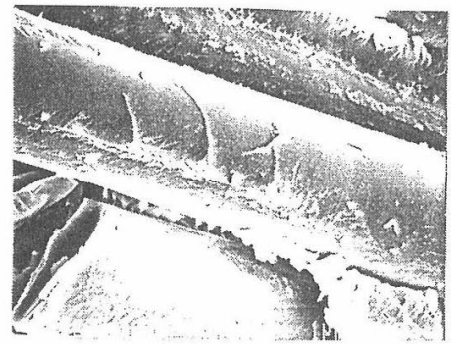

e) Rpory si 1 ane (MDI)

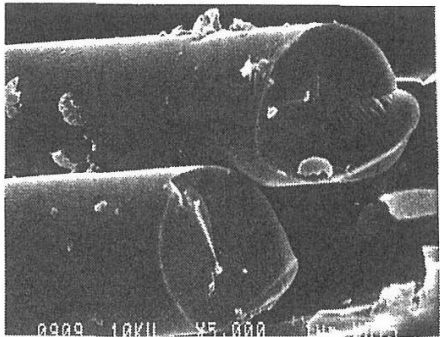

d) Ving 1 i i 1 ane (MDI)

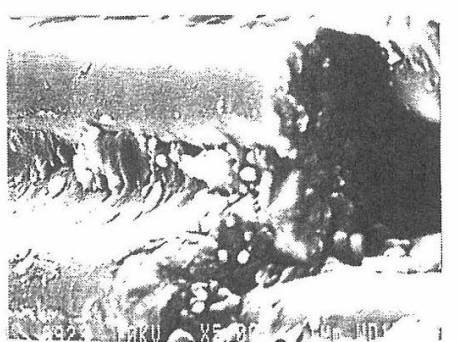

1) Amino silane (MDI)

GF s u r f a ce

Fig. 11. SEM of fiber surface in $(\mathrm{CFCL}+\mathrm{GFCL})_{8}+\mathrm{CFCL}$ laminates after charpy impact. 
シラン (Fig. 10 (d)) でぜい性的な破壊様相が認めら れ，かつ層間はく離も大きく減少していることを認め た. Fig. 11 は同じ試料の破面を走査電子顕微鏡で高 倍率観察したものであるが，炭素瀻維では MDI との 界面結合（Fig. 11(b)）を，ガラス瀻維では MDI 無添 加でビニル系シラン処理（Fig. 11 (c)）がスチレンモ ノマーとの反応によって界面結合力を示し，逆に MDI 添加（Fig. 11 (d)) で界面結合力の大幅な低下を, エポキシシラン (Fig. $11(\mathrm{e}))$ およびアミノシラン (Fig. $11(\mathrm{f})$ ) 処理では, MDI 添加による結合力の明瞭 な改善効果を示唆している.

\section{$3 \cdot 2$ MDI 添加量と特性の最適化}

ガラス繊維の表面処理剤をエポキシシランとして, 第 3 成分としての MDI の最適配合量を検討した. マ トリックス樹脂系の重合（架橋）反応がスチレンモ， マーの付加重合によるものであるため, 必ずしも $\mathrm{EPA}$ の $\mathrm{OH}$ 当量と同量の添加が材料特性を最適化す るものでないことを考慮した．前述した理由によって， 弾性率は MDI 添加量の変動にほとんど影響を受けな かった. Fig. 12 およびFig. 13 に GF 系，CF 系およ び $\mathrm{CF} / \mathrm{GF}$ 交互積層ハイブリッド系の $2 \mathrm{~mm}$ 厚さ成形 板の ILSS と曲げ強度試験の結果をそれぞれプロッ トした. ILSS および曲げ強度に関してはいずれの積

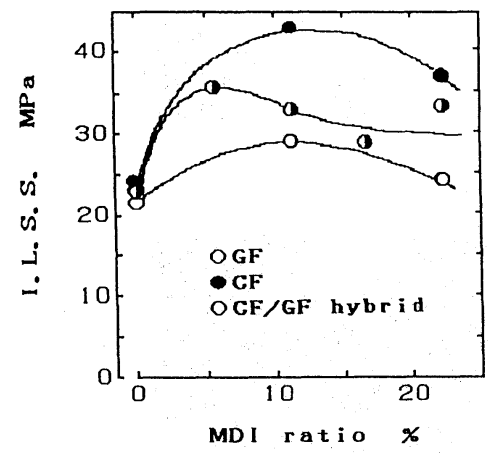

Fig. 12. ILSS of CF, GF and CF/GF hybrid laminates versus adding amount of MDI.

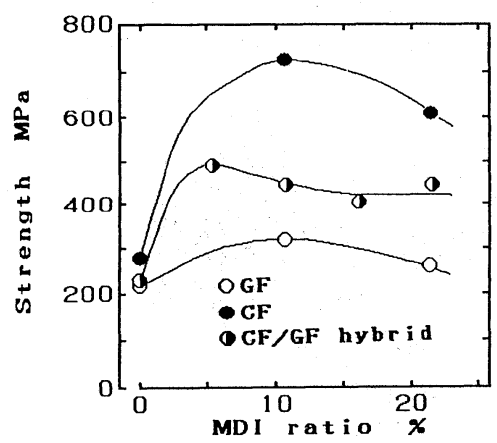

Fig. 13. Flexural bending strength of $\mathrm{CF}, \mathrm{GF}$ and $\mathrm{CF} / \mathrm{GF}$ hybrid laminates versus adding amount of MDI.

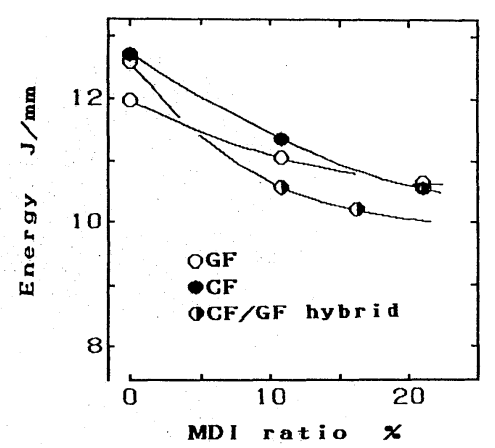

Fig. 14. Penetrating impact energy of $\mathrm{CF}, \mathrm{GF}$ and $\mathrm{CF} / \mathrm{GF}$ hybrid laminates versus adding amount of MDI.

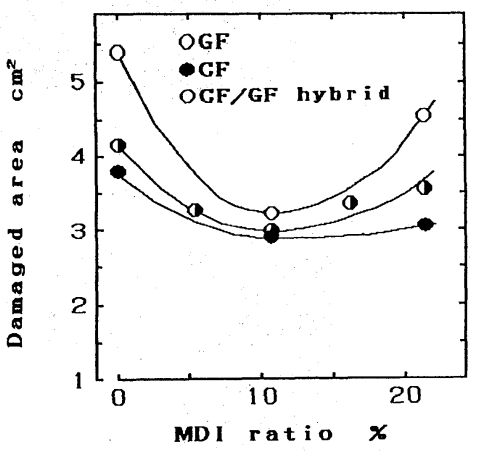

Fig. 15. Damaged area by penetrating impact of $\mathrm{CF}, \mathrm{GF}$ and $\mathrm{CF} / \mathrm{GF}$ hybrid laminates versus adding amount of $\mathrm{MDI}$.

層板についても MDI 添加量 $5.4 \%$ (1/4OH 当量) $10.8 \%$ (同 $1 / 2$ 当量) の範囲にピークが存在している ことを認めた. 貫通衝撃特性については Fig. 14 およ び Fig. 15 に吸収エネルギーおよび損傷面積をそれぞ れプロットした. MDI 添加量の増加につれて吸収エ ネルギーは低下するが，損傷面積は，層間はく離が主 要因であるため, 曲げ強度と同様の範囲に最小ピーク を示した．衝撃吸収エネルギーだけが他の特性と異 なってピークを持たない理由として，骨格 EPA とス チレンモノマーおよび MDI の両者の反応性が上げら れる. MDI は混合と同時に EPA とのウレタン化反 応を進行させるため, スチレンと EPA の付加重合に 影響を与えることが考えられる。.つまり，MDI 添加 量は適量領域では界面結合力および層間接着性を改善 し，複合材料のぜい性化を進めるが，系の組成物間の 反応の偏りを生じる添加率領域では, 逆にマトリック スの不均質性あるいはぜい弱化を招くことを示唆して いる. 他の特性がピークを持つのも同様の理由である と考えられる. 衝撃吸収エネルギーの場合は, ぜい弱 化の影響が強く，特性ピークを示さなかったものと考 えられる。

本手法の特徵は, 従来工程の中で, 現場配合によっ 
て簡単に目的が達成されることにある，生産性も， MDI 添加混合工程が追加されるだけで，ほとんど変 わらない.しかも，それによって先進複合材料である エポキシ系 CFRP あるいは CF/GF ハイブリッド材 料に相当する機械的特性を得ることができるところに ある．もちろん，成形収縮率等のエポキシ樹脂の有す る優れた特徴を凌駕することは，基本の樹脂の化学的 性質が異なるため，他の手法に頼らざるを得ない側面 もあるが，前報で報告したように耐熱性も向上するな どの産業上のメリットが多くある，その反面で，MDI の反応性の高さから，例えば高度な工場内湿度管理の 要求など, 汎用樹脂と異なる管理項目が生じる. しか し, 汎用 FRP の工程をそのまま適用することを前提 にした手法であることからコストメリットの高いもの として実用性を高めてゆく必要がある。 今後 CAI お よび疲労挙動等の実用的な特性等も明らかにしてゆき たい.

\section{$3 \cdot 3$ 繊維界面-第 3 成分-EPA の接合機構}

$3 \cdot 1$ 節および $3 \cdot 2$ 節で述べた，第 3 成分 (MDI) に よる特性改善効果を化学的な側面から考察してみると, ある確率で化学的結合が生成していると考えられる. その場合の結合様式として，炭素繊維およびガラス繊 維を対象とした推定反応機構を Fig. 16 および Fig. 17

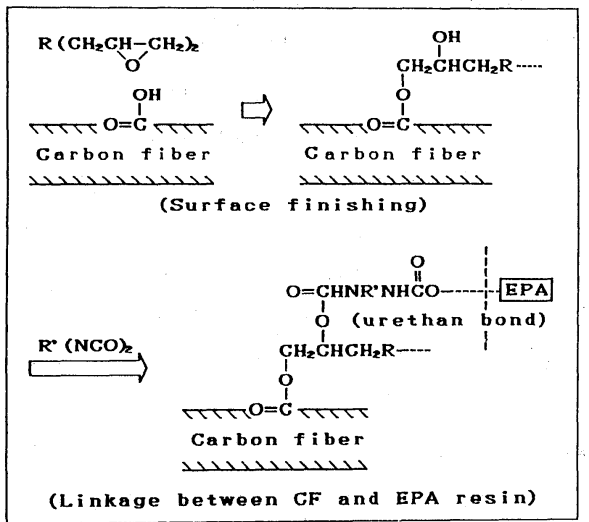

Fig. 16. Estimated chemical reaction among CF surface, MDI and EPA.

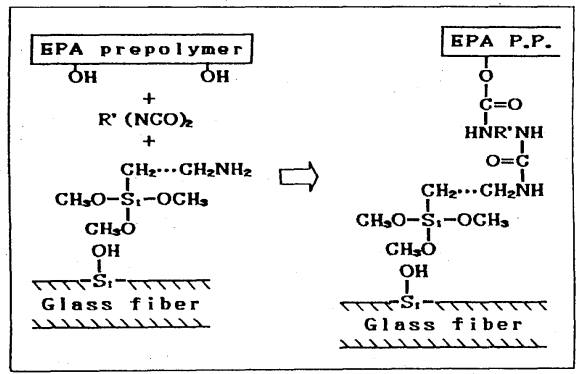

Fig. 17. Estimated chemical reaction among GF surface, MDI and EPA.
に示す．結合様式としては，ある確率でエステル，ウ レタン，ユリア結合等共有結合の生成によって，繊維 界面結合力に加えて, 異種繊維層内・層間の結合力を 高めることが考えられる。 その結果, 異種繊維層間に おいても結合力の向上が得られるものと考えられる. MDI を含まない現行の樹脂系における層間の結合様 式は, 従来から不飽和ポリエステル樹脂系で $\mathrm{CF} / \mathrm{GF}$ ハイブリッド複合材料の欠点とされてきた機械的特性 の低下を明確に示すものと考えられる，さらに，繊維 表面処理剂抢よび第 3 成分の化学的構造を考慮するこ とによって, 要求特性に応じた複合材料の創生も可能 である.たとえば，フレキシブルな構造を選択するこ とによってじん性を高める等である.

\section{4 結 言}

今後ますます普及すると考えられる高性能繊維補強 材を工業的に有効に活用する必要があり，その場合界 面結合だけでなく，異種㵶維間あるいはマトリックス 樹脂系との結合力を生じる反応系の検討も重要な課題 である. 化学的手法からの高性能複合材料へのアプロ 一チは，工業分野へ ACM を普及させる重要な手法の 一つと考えられる. 本報では, 炭素繊維／ガラス繊維 ハイブリッド複合材料の表面処理剤およびマトリック ス樹脂としてのエポキシアクリレート樹脂のそれぞれ の反応性に着目して，この両者と反応性を有するイソ シアネート化合物を第 3 成分として採用し, 層内・層 間結合力, ひいては機械的特性のかなりの改善効果を 実現できた。ささらに詳細な研究によって，特性の向上 はさらに見込まれることを付け加えておきたい. (平成 3 年10月31日 日本材料学会第 36 回 FRP 総合講演会にて一部講 演)

\section{参 考 文 献}

1 ) 好満芳邦, 下原伊智郎, 大橋俊彦, 坂田純一, 奇橋 昭, 材料, 41, 362 (1992).

2 ) 好満芳邦, 下原伊智朗, 寄橋 昭, 中本智之, 強化プラ スチックス, 38, 12 (1992).

3 ) 影山和郎, 小林孝行, 日本複合材料学会誌， 13，265 (1987).

4) 好満芳邦, 土取 功, 下原伊智朗, 材料, 40, 347 (1991).

5 ) Y. Suzuki, M. Murakoshi and J. Saitoh, 42nd SPI, Ses. 10-A (1990).

6) Gail L. Dolan, 20th SAMPE Tech. Conf., 20, 34-35 (1988).

7 ) Russel L. Turpin and Anthony L. Green, 35th SAMPE Sym., 1079 (1990).

8 ) B. Z. Jang, C. Z. Wang, B. P. Jang and R. H. Zee, 21st SAMPE Tech. Conf., 825 (1989).

9 ) 河津幸雄, 野口健一, 日本材料学会 20th FRP シンポジ ウム前刷, 31 (1991) 